\title{
WOJCIECH ZAKRZEWSKI
}

\section{O ingerencji prawodawczej w wolność słowa w okresie PRL}

The legislative interference in the freedom of expression during the period of the Polish People's Republic

\section{WPROWADZENIE}

ażdy Jubileusz skłania do refleksji nad upływem czasu mierzonego
zarówno indywidualnie, jak i przez pryzmat zbiorowych doświad-
czeń. Przy takiej okazji zastanawiamy się także, w jaki sposób losy jednostkowe i grupowe splatają się i wzajemnie warunkują. Zadajemy sobie również pytanie, czy czas i historia uczą nas pokory.

Jestem głęboko przekonany, że historia może spełniać właściwą rolę, gdy będziemy postrzegali dzieje przede wszystkim w ich ówczesnym kontekście, oczami ich uczestników i stosowanymi przez nich miarami. ${ }^{1}$ Postanowiłem zatem dać przykład wycinkowego stanu prawnego wolności słowa w Polsce i jego, dziś historycznej, oceny w powiązaniu z fragmentem losów autora. Prezentuję poniżej oryginalny tekst mojego artykułu, który złożyłem w „Państwie i Prawie" w 1983 r. Tekst otrzymał pozytywną recenzję redakcyjną profesora Wojciecha Sokolewicza, ale ze względu na stanowisko cenzury nie miał szansy na publikację. Maszynopis przedstawionego tu artykułu zwrócono mi w Warszawie w styczniu 1984 r., w przeddzień mojego wyjazdu na stypendium Szkoły Prawa Uniwersy-

\footnotetext{
${ }^{1}$ Krytycznego czytelnika dzieł poświęconych historii dziwić i niepokoić musi refleksja, jak wiele faktów historycznych jest wynikiem selekcji i interpretacyjnych wyborów historyków, którzy na dodatek kierują się regułami czasów im współczesnych. Trafnie, choć dość arogancko, ujął to Edward H. Carr: „Historyk zbiera fakty, zabiera je do domu, następnie gotuje i podaje zainteresowanym tak, jak mu się akurat podoba", E. H. Carr; What is history? University of Cambridge and Penguin Books, 1961, s. 18. Por. także pouczające w tej mierze rozważania J. Topolskiego o wzorach badania historycznego, J. Topolski, Metodologia historii, PWN, Warszawa 1973, s. 57-211.
} 
tetu Harwarda. Zabrałem go więc za ocean. Dzięki temu mój „prohibit" uzyskał niespodziewanego czytelnika w osobie profesora Stanisława Barańczaka, który dopiero po jego lekturze i dyskusji ze mną uwierzył, że moje akademickie wizyty u niego na Wydziale Slawistyki Harwardu nie mają żadnego ukrytego celu - Takie to były czasy!

Czytelnik poniższego artykułu, obejmującego regulację wolności słowa i druku do początku lat 80. ubiegłego stulecia, zauważy z pewnością ślady autocenzury. To jeden z wielu negatywnych skutków prewencyjnej kontroli słowa istotny dla oceny faktycznej realizacji analizowanej wolności. Nie zmieniając i nie ukrywając niczego w prezentowanym tekście, adresuję go głównie do ludzi młodych, by ich przekonać bądź utwierdzić w przekonaniu, że kilkadziesiąt lat w rozwoju urządzeń ustrojowych państwa to niewiele, a zdobycze demokracji trzeba chronić. Korzystanie bowiem z wolności słowa zawsze napotkać może naśladowców dawnych „włodarzy" Polski z okresu 1944-1952 i PRL chętnych, by zakrzyknąć, że „wolność nie może służyć wrogom demokracji". A wrogów znowu określaliby rządzący wspierani przez samozwańczych trybunów - ,specjalistów" od moralności i demokracji. Historia uczy więc, by mieć się na baczności. Sapere aude!

Popatrzmy w przeszłość:

\section{REGULACJA PRAWNA WOLNOŚCI SŁOWA I DRUKU W PRL}

\section{Konstytucyjne unormowanie wolności słowa i druku}

Konstytucyjna zasada wolności słowa jest wyrazem prawnego uznania w życiu państwowym swobody opinii, a tym samym - autonomii osobowości ludzkiej. Znaczenie wolności słowa obywatela dla jego działalności publicznej, demokratycznego funkcjonowania zbiorowości, jaką jest państwo, wskazuje, że jest to jedno z najbardziej ważkich, jeżeli nie najistotniejszych praw politycznych. ${ }^{2}$ Jego istnienie warunkuje prawidłowe korzystanie z pozostałych praw tej kategorii.

Możliwość swobodnego wyrażania i wymiany opinii dotyczy wszelkich form ich uzewnętrzniania, a więc słowa mówionego, pisma, obrazu itp. Stąd różnie

${ }^{2}$ Wolność słowa jest podstawowym środkiem społecznej aktywności, nie sposób więc przypisywać jej wyłącznie politycznego charakteru. Niemniej podstawowa jej funkcja polega na umożliwieniu obywatelom uczestnictwa w życiu politycznym. Stąd słuszniejsze wydaje się stanowisko tych autorów, którzy traktują ją jako prawo polityczne, a nie osobiste; por. A. Burda, Prawa obywatelskie w konstytucjonalizmie socjalistycznym, [w:] Studia z zakresu konstytucjonalizmu socjalistycznego, Ossolineum 1969, s. 189; W. Skrzydło, Podstawowe prawa polityczne obywateli PRL, [w:] Podstawowe prawa i obowiazki obywateli PRL w okresie budowy rozwiniętego spoleczeństwa socjalistycznego, Warszawa 1976, s. 45; por. przykładowo odmienny pogląd: F. Siemieński, Prawo konstytucyjne, Warszawa-Poznań 1976, s. 136; ciekawą propozycję klasyfikacji przedstawia A. Michalska (Podstawowe prawa człowieka w prawie wewnętrznym a pakty praw człowieka, Warszawa 1976). 
formułowane definicje wolności słowa i druku wskazują na szeroki jej zakres. Przyjmuje się, że wolność ta oznacza możność nieskrępowanego (w ramach obowiązujących przepisów prawa) tworzenia, manifestowania i wymiany idei, opinii, informacji za pośrednictwem dostępnych form przekazu i rozpowszechniania, poczynając od najprostszych, takich jak wystąpienia na zebraniu, aż po tak złożone, jak prasa periodyczna i nieperiodyczna, film, radio, telewizja. ${ }^{3}$

Tak ogólne pojęcie wolności słowa charakteryzuje generalną zasadę funkcjonowania nowożytnego państwa. Nie znaczy to jednak, pomijając w tym miejscu kwestię granic tego prawa, by warunki państwa socjalistycznego nie wpływały modyfikująco na pewne istotne elementy wolności słowa. Nabiera ona w ustroju socjalistycznym szczególnego znaczenia. Przyczyną tego - oprócz założeń ustrojowych stwarzających przesłanki realizacji tego prawa - jest również, a może przede wszystkim, nowa rola państwa socjalistycznego. Powoduje ona z jednej strony wzrastający wpływ państwa na kształtowanie się różnorodnych stosunków społecznych, postaw i światopoglądu obywateli, z drugiej strony - potrzebę jawności poczynań państwa oraz społecznego oddziaływania (zwłaszcza w drodze kontroli) na funkcjonowanie jego rozbudowanego aparatu. Determinuje to nowe elementy wolności słowa. Nie można jej dłużej rozpatrywać jako domeny głównie działalności jednostek, której korelatem jest wyłącznie obowiązek państwa do nieingerencji. Urzeczywistnienie wolności słowa w socjalizmie wymaga bowiem w dużej mierze współdziałania społeczeństwa z aparatem państwowym. Gros relacji między obywatelem a państwem w procesie realizacji tej wolności sprowadza się do posiadanych przez jednostkę czy grupę obywateli uprawnień, kompetencji, a w relatywnie mniejszym stopniu - wolności. Konstytucyjna wolność słowa i druku oznacza więc w pierwszym rzędzie prawo obywateli do korzystania ze środków masowego przekazu informacji - prawo do pełnej, zgodnej z prawdą informacji oraz prowadzenia krytyki za pośrednictwem tych środków.

Punktem wyjściowym analizy regulacji prawnej wolności słowa na gruncie Konstytucji PRL powinno być unormowanie tej wolności w ustawie zasadniczej. Spełnianie głównie politycznej, a nie prawnej funkcji przez konstytucję, charakterystyczne dla całego okresu jej dotychczasowego obowiązywania, nie upoważnia do rozpatrywania praktyki konstytucyjnej w oderwaniu od treści norm konstytucyjnych. Normy te wyznaczają bowiem nie tylko kierunek przyszłych rozwiązań prawnych (stanowiących realizację konstytucyjnych zasad), lecz również służą jako kryterium oceny konstytucyjności tych rozwiązań. ${ }^{4}$

${ }^{3}$ Por. B. Dobkowski, Konstytucyjne prawa i obowiazki obywateli PRL, Warszawa 1979, s. 193; L. Wiśniewski, Wolność stowa i druku, [w:] Podstawowe prawa i obowiązi obywateli PRL, Warszawa 1978, s. 33.

${ }^{4} \mathrm{~W}$ państwie, w którym brak jest specjalnego organu badającego zgodność i prawa z konstytucją, szczególny obowiązek zajmowania się tym problemem spoczywa na nauce prawa konstytucyjnego. 
Konstytucyjna wolność słowa i druku jest jednym z praw najlakoniczniej unormowanych w ustawie zasadniczej. W art. 83 ust. 1 Konstytucja stanowi: „Polska Rzeczpospolita Ludowa zapewnia obywatelom wolność słowa, druku”, zaś w ust. 2:

Urzeczywistnieniu tej wolności służy oddanie do użytku ludu pracującego i jego organizacji drukarni, zasobów papieru, gmachów publicznych i sal, środków łączności, radia oraz innych niezbędnych środków materialnych.

Sformułowanie ust. 1 wskazuje, że twórcy konstytucji użyli tradycyjnej formuły zaczerpniętej z konstytucjonalizmu burżuazyjnego. Pamiętając, że konstytucja posługuje się najszerszymi pojęciami, stwierdzić można, że terminy „słowo” $i$,druk” obejmują wszelkie formy komunikowania się, a więc szeroko rozumianą prasę, radio, film, telewizję itd.

Postanowienie art. 83 ust. 1 pozostaje w ścisłym związku z art. 9. Z obowiązku państwa „zdawania narodowi sprawy ze swej działalności” , „wyjaśnienia masom pracującym zasadniczych celów i wytycznych polityki władzy ludowej w poszczególnych dziedzinach działalności państwowej, gospodarczej i kulturalnej" (art. 9) wynika zasada jawności życia politycznego, a tym samym prawo obywateli do informacji, prawo do społecznej kontroli i krytyki działalności państwowej. ${ }^{5}$ Podobnie ogólną regułę można odtworzyć na podstawie art. 83 ust. 2. Uwzględniając swoistą interpretację doktryny marksistowskiej, dokonywaną przez twórców konstytucji w duchu uznania niesprzeczności między społeczeństwem a państwem, trzeba przyjąć, że realna treść tego przepisu sprowadza się do ustanowienia reguły, że wskazane środki materialne po przejęciu przez państwo powinny być, w zakresie w jakim państwo (stosownie do zasady rozwojowego charakteru praw - art. 67 ust. 1) uzna to za stosowne, oddane bezpośrednio do użytku ludu pracującego.

Oczywiście obowiązki państwa, wynikające ze wskazanych przepisów konstytucji, ze względu na swój ogólny charakter mogą stanowić jedynie dyrektywy kierunkowe polityki państwa, w tym działalności legislacyjnej. Przy ocenie realizacji tych obowiązków można więc posługiwać się prawie wyłącznie kryterium politycznej, a nie prawnej zgodności działań państwa z treścią konstytucji.

Bliższe ustalenie treści konstytucyjnej wolności słowa, a przez to sytuacji prawnej obywateli w tej mierze może jedynie bazować na negatywnym znaczeniu tej wolności, tzn. ustaleniu zakresu jej reglamentacji prawnej.

${ }^{5}$ Przedstawiciele centralnych organów PZPR skłonni są nawet uważać, że ,,artykuł 5 (obecny art. 9) Konstytucji wyraźnie mówi o obowiązku informowania społeczeństwa przez organy państwowe"; por. wystąpienie członka Biura Politycznego KC PZPR, w: Społeczna użyteczność wiedzy o prasie, Kraków 1967, s. 18. Na założeniach wynikających z art. 5 Konstytucji oparto również ocenę działalności rzeczników prasowych w centralnych instytucjach państwowych - I. Tetelowska, Rola rzeczników prasowych w polskich instytucjach centralnych, OSBP Kraków 1974, s. 1. 
Niezależnie od sposobu interpretacji odnośnych postanowień konstytucji jako immanentną granicę praw politycznych, w tym także wolności słowa, przyjmuje się $\mathrm{w}$ doktrynie interes ludu pracującego miast i wsi. ${ }^{6}$ Wszelkie więc korzystanie $\mathrm{z}$ wolności słowa, które byłoby sprzeczne $\mathrm{z}$ tak rozumianym interesem, jest zakazane. Użycie tak rozciągłej i nigdzie bliżej w konstytucji niesprecyzowanej granicy korzystania z praw nie może mieć praktycznego znaczenia i służyć jako kryterium oceny, czy konkretna regulacja prawna jest zgodna, czy też nie z ustawą zasadniczą. W praktyce więc o granicach wolności słowa mają decydować akty niemające rangi konstytucyjnej. ${ }^{7}$ F. Siemieński stwierdza ponadto, że konstytucja, zapewniając obywatelom określone prawa i wolności, przyjmuje tym samym zasadę, że niedopuszczalna jest calkowita ich likwidacja w formie ustaw zwykłych. ${ }^{8}$ Uznanie słuszności tej tezy w stosunku do wolności słowa i druku oznaczałoby sprowadzenie roli konstytucji jedynie do deklaracji głoszącej, iż ...niedopuszczalna jest całkowita likwidacja wolności słowa. Jest to oczywiście konkluzja zbyt daleko idąca i przejaskrawiona, wskazuje jednak na trudności, jakie można napotkać, dążąc do ustalenia treści postanowień konstytucji.

W poszukiwaniu dodatkowych elementów treści konstytucyjnej wolności słowa, w szczególności w postaci określenia zakresu dopuszczalnej ingerencji państwa, pozostaje sprawdzić użyteczność ogólnej tezy, zgodnie z którą normy konstytucyjne bazują na ,jądrze pojęciowym” wcześniej wykształconym czy to przez istniejący porządek prawny, czy też przez naukę. ${ }^{9} \mathrm{~W}$ odniesieniu do wolności słowa wyznaczników jej treści można upatrywać zarówno w aktach prawnych uchwalonych w okresie międzywojennym, jak i w latach 1944-1952. Z okresu Polski burżuazyjnej jedynym aktem zasługującym na rozważenie jako podstawa kształtowania treści wolności słowa jest Konstytucja marcowa (art. 104 i 105). W świetle jej postanowień zakazane było wprowadzenie cenzury i systemu koncesyjnego na druki oraz silnie podkreślona była zasada legalizmu w wyznaczaniu granic ingerencji państwa. Natomiast praktyka konstytucyjna okresu międzywojennego znacznie odbiegała od tych założeń. Rządowe projekty prawa prasowego, uchylone przez Sejm rozporządzeniami Prezydenta RP z 1926 r. i 1927 r. w sprawach prasowych, Konstytucja kwietniowa z 1935 r. oraz dekret prasowy z 1938 r. stanowiły bowiem wyraz dążenia rządu do likwidacji wszelkimi sposobami opo-

\footnotetext{
${ }^{6}$ Problem ten był wielokrotnie podnoszony w literaturze przedmiotu; por. m.in. S. Rozmaryn, Konstytucja jako ustawa zasadnicza PRL, Warszawa 1967, s. 182-184; K. Opałek, Problem ograniczeń podstawowych praw i wolności obywatelskich przez ustawy, [w:] Księga pamiątkowa ku czci K. Grzybowskiego, Kraków 1971.

${ }^{7}$ F. Siemieński, Podstawowe wolności, prawa i obowiązki obywateli PRL, Warszawa 1979, S. 124.

${ }^{8}$ F. Siemieński, Prawo konstytucyjne ..., s. 162.

${ }^{9}$ Por. S. Rozmaryn, op. cit., s. 115-117.
} 
zycji politycznej, zwłaszcza o nastrojach rewolucyjnych, oraz próbę wprowadzenia w praktyce form cenzury prewencyjnej i systemu koncesyjnego.$^{10}$ Skoro więc nawet uznamy, że w poszukiwaniu demokratycznych zasad wypada nam sięgnąć do Konstytucji z 17 marca 1921 r., pomijając inne akty z okresu 1918-1939, nasuwa się pytanie, jakie znaczenie dla interpretacji wolności słowa i druku w Konstytucji lipcowej ma rozumienie odnośnych postanowień Konstytucji marcowej - szczególnie w kontekście dekretu z 1946 r. o utworzeniu Głównego Urzędu Kontroli Prasy Publikacji i Widowisk. Inaczej rzecz ujmując, czy elementy pojęcia wolności słowa w postaci zakazu cenzury, systemu koncesyjnego i zasady legalizmu ingerencji państwa zachowały swą aktualność w okresie powojennym. ${ }^{11}$ W świetle postanowień Manifestu PKWN, Deklaracji Sejmu Ustawodawczego z 1947 r. nie można obronić tezy, że Konstytucja marcowa w zakresie normowania praw i wolności obywatelskich obowiązywała w tym czasie w jej literalnym brzmieniu. Potwierdza to praktyka ustrojowa lat 1944-1952 - postanowienia Konstytucji marcowej były często inaczej rozumiane i modyfikowane. Wynikało to zarówno z faktu, iż przywrócenie mocy obowiązującej Konstytucji marcowej miało swe źródło w decyzjach władzy ludowej, jak i z nowego klasowego charakteru państwa. ${ }^{12}$ Zarówno Manifest PKWN, jak i uchwalona w 1947 r. przez Sejm Ustawodawczy deklaracja w przedmiocie realizacji praw i wolności obywatelskich nie zawierają ani identycznego z Konstytucją marcową katalogu praw, ani takiego samego ich sformułowania. Prowadzi to do wniosku, że wolność słowa i druku w rozumieniu Konstytucji z 1921 r. w okresie 1944-1952 była ogólną dyrektywą dla ustawodawstwa, zgodnie z którą wolność słowa winna być traktowana jako zasada, zaś wyjątki od niej muszą być określone ustawowo. ${ }^{13}$ Potwierdza to pośrednio sformułowanie deklaracji Sejmu Ustawodawczego, głoszące, iż „wyzyskiwaniu praw i wolności obywatelskich do walki z demokratycznym ustrojem Rzeczypospolitej Polskiej winny zapobiegać [wyróżnienie moje] ustawy”.

Chociaż w okresie przygotowań do uchwalenia Konstytucji PRL nie zajmowano się nawiązaniem do tradycji Konstytucji z 1921 r., nie sposób jej pominąć, interpretując wolność słowa i druku w brzmieniu obecnego art. 83 Konstytucji. Można stwierdzić, że do ukształtowanego w drodze tradycji ,jądra pojęciowego" konstytucyjnej wolności słowa należy uznanie, iż stanowi ona zasadę ustrojową,

${ }^{10}$ Por. M. Pietrzak, Reglamentacja wolności prasy w Polsce (1918-1939), Warszawa 1963, rozdział I.

${ }^{11} \mathrm{~W}$ trakcie 11 sesji KRN jedna z posłanek postawiła zarzut, iż dekret o utworzeniu Głównego Urzędu Kontroli Prasy, Publikacji i Widowisk jest sprzeczny z art. 105 Konstytucji marcowej; por. spraw. stenogr. z posiedzeń 11 sesji KRN, łam 430.

${ }^{12}$ Por. K. Działocha, J. Trzciński, Zagadnienie obowiąywania Konstytucji marcowej w Polsce Ludowej 1944-1952, Wrocław 1977, rozdział III, pkt 3 i 4.

${ }^{13}$ Inną natomiast kwestią jest ocena rozwiązań prawnych dekretu o cenzurze z 1946 r. dotyczących jej funkcjonowania. Zakres faktycznej arbitralności Urzędu Kontroli Prasy, Publikacji i Widowisk wprowadzony dekretem bez wątpienia nie dawał się pogodzić z duchem demokracji. 
którą można ograniczyć, nie wyłączając cenzury i systemu koncesyjnego, lecz nie na tyle, by z wyjątków restrykcje te mogły przerodzić się w zasadę, zakres reglamentacji wolności słowa powinien być określony ustawowo, zaś przepisy te, skoro stanowią wyjątek od zasady, nie mogą być tłumaczone rozszerzająco.

Podstawową gwarancją właściwego działania aparatu państwowego $\mathrm{w}$ tej mierze może być ustawodawstwo. Tylko ustawa jest właściwa do wprowadzenia i regulowania reglamentacji wolności słowa i druku. Wniosek taki płynie z koncepcji materii ustawowej, której w doktrynie powszechnie przypisuje się rodowód konstytucyjny i rangę generalnej normy ustawy zasadniczej. ${ }^{14}$

Zbadanie ewolucji stanu prawnego $\mathrm{w}$ dziedzinie wolności słowa i druku w okresie obowiązywania Konstytucji PRL pozwoli m.in. sprawdzić skuteczność tak skonstruowanej gwarancji.

\section{Regulacja wolności słowa i druku na gruncie Konstytucji PRL}

Analiza reglamentacji omawianej wolności będzie w pierwszym rzędzie dotyczyła prawnej regulacji zasad zakładania i działalności przedsiębiorstw i instytucji, których celem jest gromadzenie, przekazywanie różnych form wytworu intelektu, zasad ich rozpowszechniania i kontroli w tym zakresie oraz granic swobody wypowiedzi.

Unormowanie wskazanych zagadnień nastąpiło w sposób fragmentaryczny i prowizoryczny jeszcze przed uchwaleniem Konstytucji PRL. Określone zaszłości życia politycznego i praktyki prawotwórczej na gruncie Konstytucji PRL sprawiły, że owe regulacje, wbrew ich niepełnemu, przejściowemu charakterowi, obowiązywały przez długi okres po uchwaleniu ustawy zasadniczej i przesądziły w dużej mierze o kierunku późniejszych zmian. Z tego względu celowe jest przedstawienie najpierw stanu prawnego w dziedzinie wolności słowa i druku ukształtowanego przed $1952 \mathrm{r}$.

Przede wszystkim ustawodawca uregulował prowadzenie drukarń. Reglamentacja działalności zakładów, w których powstaje słowo drukowane, jest ściśle związana z zagadnieniem nadzoru państwa nad prasą i rozpowszechnianiem druków ${ }^{15}$ oraz odzwierciedla zakres wpływu, jaki państwo chce wywierać w tej mierze. Ustawą z 3 stycznia 1946 r. o przejściu na własność państwa podstawowych gałęzi gospodarki narodowej ${ }^{16}$ został ustanowiony monopol państwa w odniesieniu do własności przemysłu poligraficznego i drukarskiego (art. 3 pkt. 17). Rozporządzenie Rady Ministrów miało uregulować, które kategorie przedsiębiorstw zostaną przekazane na własność organizacji politycznych lub społecznych, sto-

${ }^{14}$ Por. W. Zakrzewski, Z zagadnień form prawotwórczej realizacji praw $i$ wolności obywatelskich w PRL, „Annales UMCS” 1980, vol. XXVII, 4, s. 48-51.

${ }^{15}$ M. Lityński, K. Stępińska, Prawo o prasie, Kraków 1966, s. 569.

${ }^{16}$ Dz. U. nr 3, poz. 17. 
warzyszeń i spółdzielni. Rozporządzenie to, wydane w 1949 r. ${ }^{17}$ ustaliło zasadę, że na własność tych organizacji mogą przejść jedynie niewielkie zakłady drukarskie. ${ }^{18}$ Ich prowadzenie zostało oparte na systemie koncesyjnym. Rozporządzenie RM z 12 maja 1949 r. ${ }^{19}$ nie ustalało jednak ani warunków uzyskania koncesji, ani powodów jej cofnięcia, pozostawiając to do dyskrecjonalnego uznania organu administracji udzielającego pozwolenia.

Nadzór państwowy nad działalnością zakładów poligraficznych został unormowany w kilku aktach różnej rangi. Najogólniejsze postanowienia zawierał dekret z 5 lipca 1946 r. o utworzeniu Głównego Urzędu Kontroli Prasy, Publikacji i Widowisk. ${ }^{20} \mathrm{~W}$ art. 2 pkt 4 ustanawiał on właściwość Głównego Urzędu dla kontroli tego rodzaju zakładów. Jednocześnie określenie zakresu i trybu wykonywania tej kontroli dekret odsyłał do rozporządzenia RM. Upoważnienie to nie zostało jednak zrealizowane, a kwestie przeprowadzania kontroli drukarń i innych zakładów poligraficznych zostały w 1949 r. unormowane zarządzeniem Naczelnego Dyrektora Głównego Urzędu KPPiW. ${ }^{21} \mathrm{~W}$ odniesieniu do pozostałych spraw nadzoru administracyjnego nad działalnością drukarń obowiązywała nadal ustawa z 1932 r. o bezpłatnym dostarczaniu druków dla celów bibliotecznych i urzędowej rejestracji ${ }^{22}$ oraz wykonujące ją rozporządzenie z 1947 r. ${ }^{23}$ Ogólne przepisy dotyczące działalności prasy periodycznej zawarte były w dekrecie o utworzeniu GU KPPiW, dekrecie z 1947 r. o zniesieniu Urzędu Ministra Informacji i Propagandy ${ }^{24}$ oraz uchwale RM z 1949 r. w sprawie państwowej działalności wydawniczej. ${ }^{25}$ Akty te w sposób bardzo ogólny określały właściwość Prezesa RM w sprawach prasy (art. 2 dekretu z 1947 r.) oraz ustanawiały dwie zasady dotyczące zakładania i wydawania czasopism. W odniesieniu do działalności wydawniczej jednostek państwowych cytowana uchwała RM wprowadzała system zgłoszeniowy (§ 2), pozostawiając Prezesowi RM decyzję o wydawaniu czasopisma (§ 8). Prasową działalność wydawniczą podmiotów niepaństwowych dekret o utworzeniu GU KPPiW uzależniał od zezwolenia tego Urzędu. Sam dekret nie zawierał postanowień określających warunki uzyskania takiego zezwolenia ani też zasad

${ }^{17}$ Dz. U. nr 26, poz. 193.

${ }^{18}$ Potwierdza to uchwała nr 832 Prezydium Rządu z 8 grudnia 1951 r. w sprawie przekazania drobnych (wyróżn. moje) zakładów przemysłu poligraficznego radom narodowym, MP nr 100, poz. 1469 .

${ }^{19}$ Dz. U. nr 34, poz. 245.

${ }^{20}$ Dz. U. nr 34, poz. 210 z późn. zm.

${ }^{21}$ Instrukcja o trybie wykonywania i rozpowszechniania utworów graficznych przez zakłady poligraficzne na całym obszarze państwa (niepublikowana). Akt ten składał się z 7 rozdziałów - 36 obszernych paragrafów.

${ }^{22}$ Dz. U. nr 33, poz. 347.

${ }^{23}$ Dz. U. nr 64, poz. 374.

${ }^{24}$ Dz. U. nr 32, poz. 147.

${ }^{25}$ MP nr A-102, poz. 1196. 
i trybu jego udzielania. Zapowiedziane rozporządzenie mające regulować te kwestie nie zostało wydane.

Nie wprowadzając monopolu państwa w dziedzinie prasy, istniejący w latach 1944-1952 system prawnej regulacji swobody wypowiedzi w tej formie zapewnił uprzywilejowaną pozycję wydawnictwom prasowym o charakterze rządowym bądź partyjno-rządowym. Celowi temu służyło m.in. powołanie na podstawie dekretu z 26 października 1945 r. o utworzeniu Polskiej Agencji Prasowej PAP ${ }^{26}$ przedsiębiorstwa państwowego, którego przedmiotem działalności miało być informowanie społeczeństwa polskiego o wszelkich przejawach życia w kraju i za granicą oraz informowanie zagranicy o życiu polskim (art. 3 pkt a), a także wprowadzenie monopolu tego przedsiębiorstwa w dziedzinie otrzymywania informacji od jednostek państwowych podporządkowanych Radzie Ministrów. Charakter zbliżony do państwowego, wbrew zachowaniu nazwy „spółdzielnia”, uzyskało największe wydawnictwo prasowe RSW-Prasa powstałe z połączenia spółdzielni wydawniczych dwóch partii - PPR i PPS. Fuzja ta dokonana została bowiem aktem rządowym - uchwałą Rady Ministrów ${ }^{27}$, a kolejna uchwała 65/54 Prezydium Rządu w sprawie uprawnień RSW-Prasa (niepublikowana) przyznała temu wydawnictwu, w pewnym zakresie, pozycję centralnego urzędu (wskazuje na to np. udział w budżecie centralnym, wykonywanie przez Zarząd Główny wydawnictwa niektórych uprawnień centralnych urzędów - pkt 1-3 cytowanej uchwały). Uprzywilejowanie działalności państwowej w dziedzinie prasy było podyktowane unormowaniem w 1949 r. możliwości wprowadzenia wyłączności przedsiębiorstwa państwowego w przyjmowaniu zamówień na dostawy i rozpowszechnianie w kraju i za granicą wszelkich wydawnictw. Do takiego blankietowego upoważnienia sprowadzała się treść art. 1 ustawy o prenumeracie i kolportażu czasopism i wydawnictw ${ }^{28}$. Rozporządzenie Prezesa RM, wydane na tej podstawie, nadało prawo wyłączności w wymienianym zakresie w odniesieniu do prasy Państwowemu Przedsiębiorstwu Kolportażu „Ruch”. ${ }^{29}$

Przekazywanie informacji za pośrednictwem innych niż prasa środków masowej informacji zostało uregulowane na zasadzie monopolu państwowego. Dekretem z 1951 r. o utworzeniu i zakresie działania Komitetu do spraw Radiofonii „Polskie Radio" ${ }^{30}$ tworzenie i przekazywanie programów radiofonicznych i telewizyjnych do powszechnego odbioru zastrzeżono do wyłącznej kompetencji tego centralnego urzędu.

Wskazane zasady organizacji środków masowej informacji oraz fakt, iż wymiana poglądów za ich pośrednictwem stanowi podstawową formę korzystania

\footnotetext{
${ }^{26}$ Dz. U. nr 50, poz. 278.

${ }^{27}$ MP z 1948 r. nr A-79, poz. 696.

${ }^{28}$ Dz. U. nr 83, poz. 497.

${ }^{29}$ Dz. U. z 1950 r. nr 35, poz. 313.

${ }^{30}$ Dz. U. nr 24, poz. 308.
} 
z wolności słowa przesądzającą o ważkości prawnego zagwarantowania prawa do informacji. Prawidłowy proces informowania społeczeństwa może bowiem odbywać się tylko w warunkach swobodnego dostępu prasy do źródeł informacji. Lata 1945-1952 pod względem prawnej regulacji tej kwestii charakteryzowało występowanie dwóch przeciwstawnych tendencji. Pierwsza z nich, występująca w latach 1945-1950, cechowała się spontanicznym tworzeniem w instytucjach państwowych różnych komórek prasowo-informacyjnych. Ich działalność niezależnie od tego, czy miała, czy też nie podstawy prawne służyła nie tyle instytucji, w której te komórki zostały powołane, co opinii publicznej. ${ }^{31}$ Pierwsze unormowanie o charakterze generalnym w dziedzinie dostępu prasy do informacji spowodowało bardzo poważne ograniczenia w dopływie informacji. Uchwała Prezydium Rządu z 1950 r. w sprawie organizacji służby prasowo-informacyjnej w urzędach i instytucjach państwowych oraz jednostkach gospodarki uspołecznionej, a także wydane na jej podstawie zarządzenie Prezesa $\mathrm{RM}^{32}$ znosiły dotychczas istniejące komórki służby prasowo-informacyjne, przekazując ich uprawnienia kierownikom tych instytucji, wyłączały spod obowiązku informowania ministerstwa: Obrony Narodowej, Bezpieczeństwa Publicznego, Spraw Zagranicznych, Handlu Zagranicznego oraz podległe im jednostki, zakazywały wydawania biuletynów informacyjnych, wprowadzały zasadę informowania prasy i radia tylko za pośrednictwem Polskiej Agencji Prasowej.

Akty te dotyczyły wprawdzie informowania przez jednostki państwowe z własnej inicjatywy, faktycznie jednak stały się skutecznym środkiem skrępowania dostępu do informacji w ogóle. Taki stan prawny pogarszał ponadto brak jasności co do obowiązywania prawa prasowego w 1938 r. przynajmniej w części dotyczącej praw i obowiązków prasy. W konsekwencji doszło do ukształtowania i utrwalenia na wiele lat bardzo niepożądanych postaw po stronie administracji, mianowicie niechęci do informowania prasy, lekceważenia wymogu pełnego i obiektywnego przedstawienia sytuacji, a po stronie prasy - pasywności, niekompetencji i braku poczucia odpowiedzialności za ogłaszane informacje i komentarze. ${ }^{33}$

W omawianym okresie w sposób fragmentaryczny unormowano również korzystanie z innych form wolności słowa, takich jak publikowanie książek, wystawianie sztuk, produkcja i rozpowszechnianie filmów. Zasady zakładania przedsiębiorstw wydawniczych książek i druków nieperiodycznych zostało zróżnicowane w zależności od podmiotów, których dotyczyły. Działalność wydawniczą jednostek państwowych uregulowano tak samo jak w odniesieniu do prasy $^{34}$, zaś

${ }^{31}$ I. Tetelowska, op. cit., s. 2-3. W omawianej dziedzinie brak było generalnej regulacji, a istniejące przepisy miały charakter instrukcji resortowych.

${ }^{32}$ MP A-123, poz. 1518; A-130, poz. 1624 oraz A-128, poz. 1584.

${ }^{33}$ I. Tetelowska, op. cit., s. 38.

${ }^{34}$ Uchwała RM z 1949 r. w sprawie państwowej działalności wydawniczej, MP nr A-102, poz. 1196. 
działalność innych podmiotów uzależniona została od uzyskania koncesji udzielanej przez odpowiedni organ administracji za zgodą Prezesa RM. Normujące tę kwestię rozporządzenie premiera z $1949 \mathrm{r}^{35}$ czy późniejszy dekret z $1951 \mathrm{r}$. o utworzeniu i zakresie działania Centralnego Urzędu Wydawnictw Przemysłu Poligraficznego i Księgarskiego ${ }^{36}$ (na mocy którego Urząd ten przejął koncesjonowanie przedsiębiorstw wydawniczych) i wydana na jego podstawie uchwała nr $578 \mathrm{RM}^{37}$ nie określały zasad i warunków udzielenia ani cofnięcia koncesji. Częściowe unormowanie tej kwestii dokonane zostało samoistnym zarządzeniem Ministra Handlu Wewnętrznego z 1949 r. ${ }^{38}$ Nadzór i koordynacja niepaństwowych jednostek wydawniczych (bez bliższego określenia ich zakresu) zostały powierzone na mocy cytowanej uchwały Centralnemu Urzędowi WPGiK. W podobnie ogólnikowy sposób zostało unormowane rozpowszechnianie poglądów za pośrednictwem filmu. Ta dziedzina wolności słowa została objęta ścisłą reglamentacją państwową wprowadzoną ustawą z 1951 r. o kinematografii. ${ }^{39}$ Ustawa ta powołała Centralny Urząd Kinematografii podległy Prezesowi RM. Produkcja filmów do publicznego wyświetlania, ich rozpowszechnianie przez podmioty niepodporządkowane Urzędowi mogły się odbywać jedynie za zgodą i na warunkach przez Urząd ustalonych (art. 4). Również sprowadzanie filmów z zagranicy zastrzeżono do wyłącznej właściwości tego Urzędu. Wydane w 1952 r. zarządzenie Prezesa $\mathrm{RM}^{40}$ dotyczące rozpowszechniania filmów powtarzało jedynie ogólne postanowienia ustawy, pozostawiając tym samym uregulowanie tych zagadnień aktom instrukcyjnym.

Wspólne dla wszystkich form korzystania z wolności słowa i druku określenie granic swobody wypowiedzi oraz system nadzoru nad rozpowszechnianiem różnych wytworów intelektu miały podstawę w cytowanym już dekrecie z $1946 \mathrm{r}$. o utworzeniu GU KPPiW. Granice wolności słowa zostały zakreślone w sposób bardzo ogólny; oprócz wskazanych przez dekret granic, co do których wprowadzono prawne sprecyzowanie ich zakresu ${ }^{41}$, dekret wymieniał takie granice, jak zakaz godzenia w ustrój PRL czy podawanie wiadomości niezgodnych z rzeczywistością, co do których zawsze istnieje duży margines mniej lub bardziej dowolnej oceny ich przekroczenia. Nie trzeba tu odwoływać się do doświadczeń płynących ze stosowania tych przepisów, by stwierdzić, że „zbyt syntetyczne

${ }^{35}$ Dz. U. nr 53, poz. 407.

${ }^{36}$ Dz. U. nr 41, poz. 309.

${ }^{37}$ MP nr A-85, poz. 1165.

${ }^{38} \mathrm{MP}$ nr 79, poz. 985.

${ }^{39}$ Dz. U. nr 66, poz. 453.

${ }^{40}$ MP nr A-51, poz. 693; por. także zarządzenie Prezesa RM z dnia 11 lutego 1953 r. w sprawie produkcji filmów przeznaczonych do publicznego wyświetlania, MP nr A-17, poz. 238.

${ }^{41} \mathrm{~Np}$. w odniesieniu do zakazu ujawniania tajemnic państwowych (art. 2 ust. 1 lit c) cyt. dekretu) obowiązywał od 1949 r. (Dz. U. nr 49, poz. 107) dekret, precyzując, co należy rozumieć przez określenie „tajemnica państwowa”. 
normy w tej dziedzinie spowodują w praktyce szereg nieporozumień". ${ }^{42}$ Gwarancją prawidłowego stosowania tak ogólnych kryteriów przekroczenia granic swobody wypowiedzi mogło być orzecznictwo sądowe. ${ }^{43} \mathrm{Na}$ podstawie jednak dekretu z 1946 r. organem sprawującym nadzór w tym zakresie został urząd centralny i jego organy terenowe. System kontroli i nadzoru oparty został na systemie cenzury prewencyjnej i objął po zmianach dekretu w $1948 \mathrm{r}$. wszystkie formy wypowiedzi. Omawiany dekret, stanowiący klasyczny przykład aktu ustawodawczego o charakterze blankietowym, nie ustalał żadnych zasad dotyczących zakresu i trybu wykonywania kontroli i nadzoru, pozostawiając tak istotne kwestie do dyskrecjonalnego uznania Głównego Urzędu KPPiW. Mimo wprowadzenia w 1952 r. upoważnienia do unormowania przez Prezesa RM zakresu i trybu wykonywania kontroli przez Główny Urząd w praktyce sytuacja nie uległa zmianie w wyniku niewywiązania się premiera z nałożonego nań obowiązku. O rozmiarach reglamentacji wolności wypowiedzi, dokonywanej na podstawie ogólnikowego upoważnienia, świadczy jeden z niewielu publikowanych w tym czasie aktów - uchwała Prezydium Rządu nr 58 z 22 kwietnia 1952 r. w sprawie druków przeznaczonych do publikacji przez plakatowanie (obowiązująca ponad 30 lat). ${ }^{44}$ Akt ten wydany bez podstawy prawnej w odniesieniu do swobody publikacji plakatów i afiszy zawierał następujące ograniczenia: właściwy Urząd KPPiW musiał dopuścić je do druku, zatwierdzić wysokość nakładu, określonego zresztą samą uchwałą, druki te nie mogły mieć innego formatu niż ustalony w uchwale ani być plakatowane w innych niż wymienione w niej miejscach.

W omawianym okresie 1945-1952 obszar wolności słowa i druku określała niewielka liczba fragmentarycznych i ogólnikowych formuł prawnych, znaczne luki w unormowaniu oraz szeroki zakres dyskrecjonalnego władztwa nadany organom administracji. Uzasadnienie istniejącego stanu rzeczy wyczerpało się wraz z zamknięciem etapu rewolucyjnych przemian naszej państwowości, czego wyrazem było uchwalenie Konstytucji PRL. Zawierała ona postanowienia pozwalające na odpowiednią do istniejącego ustroju interpretację wyrażonej w lakonicznej formule wolności słowa i druku. Dodatkowym bodźcem zmian był klimat polityczny, jaki powstał po 1956 r. Potencjalnie sprzyjał on właściwej interpretacji postanowień ustawy zasadniczej i odpowiedniemu do niej kształtowaniu prawotwórstwa w dziedzinie wolności słowa. Generalne zmiany nie nastąpiły jednak szybko po uchwaleniu Konstytucji PRL. Analiza odpowiednich unormowań prawnych pozwoli odpowiedzieć na pytanie, jak dalece praktyka prawotwórcza odbiegała od wymogów stawianych jej w ustawie zasadniczej i jakie tendencje występowały w tym zakresie.

\footnotetext{
${ }^{42}$ B. Michalski, Podstawowe problemy prawa prasowego, „Prasa Polska” 1968, nr 10, s. 30.

${ }^{43}$ M. Kafel, The press and the law, „Kwartalnik Prasoznawcy”, 1957, z. 3-4, s. 5.

${ }^{44} \mathrm{MP}$ z 1952 r. nr A-74, poz. 1183.
} 
$\mathrm{W}$ odniesieniu do pierwszego $\mathrm{z}$ omawianych zagadnień związanych z realizacją wolności słowa - prowadzenia drukarń, obowiązuje nadal system koncesyjny. W stosunku do jednostek gospodarki uspołecznionej obowiązuje nadal ogólne rozporządzenie RM z 1949 r. Prowadzenie zaś drukarń przez inne podmioty zostało na mocy rozporządzenia RM z 25 sierpnia $1958 \mathrm{r} .{ }^{45}$ uzależnione od zezwolenia Ministra Kultury i Sztuki. Jako że cytowane rozporządzenie nie zawierało zasad udzielania takiego zezwolenia, kwestie te uregulował Minister Kultury i Sztuki zarządzeniami. ${ }^{46}$

Nadzór nad przedsiębiorstwami poligraficznymi i drukarskimi sprawowany był przez GU KPPiW na podstawie ogólnikowego postanowienia art. 2 ust. 1 pkt. 4 dekretu z 1946 r. o jego utworzeniu i z braku zapowiedzianego rozporządzenia zakres i tryb tego nadzoru normowany był wieloma aktami instrukcyjnymi Prezesa GU KPPiW. ${ }^{47}$ Dopiero w 1970 r. zostało wydane zapowiedziane dekretem z 1946 r. rozporządzenie Prezesa RM. ${ }^{48}$ Zawierało ono zasady sprawowania nadzoru, przypadki wyłączenia spod niego, a szczegółowe postanowienie odsyłało do zarządzenia Prezesa GU KPPiW. Zmiana rozporządzenia w $1975 \mathrm{r} .{ }^{49}$ wprowadziła zasadę, że omawiane zakłady podlegają rejestracji, której sposób uregulują właściwe organy administracji państwowej, organizacji społecznych i spółdzielczych w uzgodnieniu z Prezesem GU KPPiW, zaś w odniesieniu do osób fizycznych i innych podmiotów niż określone wyżej zasady i tryb rejestracji określa Prezes GU KPPiW. Jednocześnie rozporządzenie to nie regulowało, jak poprzednie, zasad kontroli tych zakładów.

Podstawowe zasady dotyczące organizacji i funkcjonowania środków masowej informacji (głównie prasy) w czasie dotychczasowego obowiązywania Konstytucji PRL wbrew licznym postulatom ${ }^{50}$ i zapowiedziom, m.in. uchwałą V Zjaz-

${ }^{45} \mathrm{~W}$ sprawie zezwoleń na wykonywanie przemysłu, rzemiosła i niektórych usług przez jednostki gospodarki nieuspołecznionej - Dz. U. nr 49, poz. 242.

${ }^{46}$ Biuletyn MKiSz z 1959 r., nr 6, poz. 52 i 54; zm. zarządzeniami 11 i 12 MKiSz z 1973 r., Biuletyn MKiSz z 1971 r., nr 2, poz. 6 i 7.

${ }^{47} \mathrm{~Np}$. zarządzenie nr 4 z 8 czerwca 1956 r. i nr 2/57 z 24 kwietnia 1957 r. Prezesa Głównego Urzędu KPPiW regulujące sprawy zwolnień niektórych druków od obowiązku uzyskiwania zezwoleń na druk i rozpowszechnianie; zarządzenie nr 2 Prezesa GU KPPiW z 10 kwietnia 1965 r. wprowadzające nową „Instrukcję w sprawie rejestracji i kontroli zakładów poligraficznych [...]; akty niepublikowane.

${ }^{48}$ Dz. U. nr 6, poz. 50.

${ }^{49}$ Dz. U. nr 13, poz. 75.

${ }^{50}$ Zawierają je niemal wszystkie publikacje wydawane w ramach działalności powołanego w 1957 r. Ośrodka Badań Prasoznawczych w Krakowie. Jednoznaczny wniosek o konieczności uchwalenia ustawy prasowej nasuwa analiza obowiązujących w latach 1944-1966 regulacji prawnych w tej dziedzinie; por. na ten temat uwagi autorów pracy i autorów przedmowy i wstępu do niej - Prawo o prasie, Kraków 1966. 
du PZPR ${ }^{51}$, nie doczekały się generalnego unormowania ustawowego, a poza tym do tej pory obowiązujące, często nieaktualne przepisy nie ulegały zmianie. Zapowiedziane dekretem z 1946 r. unormowanie przez Prezesa RM zasad udzielania zezwoleń na zakładanie czasopism nie ukazało się do 1970 r. Powodem tego było częściowo unormowanie samego dekretu, bowiem jego zmiana w 1953 r. uchyliła art. 3, zgodnie z którym wymaganą formą aktu Prezesa RM było rozporządzenie. Wydawane sporadycznie przez premiera zarządzenia w tej materii miały często instrukcyjny charakter nie powoływały podstawy prawnej, ich treść sprowadzała się do przypomnienia obowiązujących przepisów, regulowały tylko pojedyncze kwestie, np. obowiązek organu KPPiW zasięgnięcia opinii właściwych organów przed wydaniem decyzji o zezwoleniu na założenie czasopisma. ${ }^{52}$ Kompleksowe zaś unormowanie warunków udzielania zezwoleń na wydawanie periodyków, wbrew postanowieniom dekretu, premier przekazał Prezesowi GU KPPiW.

Wykonanie dekretu z $1946 \mathrm{r}$. w drodze rozporządzenia nastąpiło w $1970 \mathrm{r}^{53}$ Regulowało ono w sposób generalny i pełny warunki udzielenia takiego zezwolenia (§ 10-14). Już jednak 5 lat później w wyniku zmiany rozporządzenia przepisy te zostały uchylone, a tym samym przywrócono w tym zakresie dyskrecjonalną władzę Głównego Urzędu KPPiW.

Pozostają nadal w mocy przepisy sprzed uchwalenia Konstytucji PRL dotyczące uprzywilejowanej pozycji prasy partyjno-rządowej i właściwości Prezesa RM w sprawach prasy. Nie uległy zmianie (choć wydano nowe przepisy) również zasady określające monopol państwa w dziedzinie wytwarzania i rozpowszechniania programów za pośrednictwem radia i telewizji ${ }^{54}$ oraz $\mathrm{w}$ sprawach kolportażu. ${ }^{55}$

Znamienna jest ewolucja uregulowania podstawowej przesłanki wolności słowa, jaką jest prawo do informacji. Od 1952 r. można wyróżnić kilka etapów zmian unormowania i praktyki w odniesieniu do prawa do informacji: a) 1952 1956, b) 1956-1963, c) 1963-1978, d) 1978 - do chwili obecnej. Pierwszy okres po uchwaleniu konstytucji charakteryzuje formalne i faktyczne obowiązywania cytowanych już przepisów Uchwały Prezydium Rządu i zarządzenia Prezesa RM z 1950 r. poważnie ograniczających dostęp prasy do informacji. Drugi okres zwią-

${ }^{51}$ „Partia nasza przywiązuje wielką wagę do podniesienia znaczenia i roli krytyki prasowej. W tym celu z inicjatywy partii zostanie wniesiona pod obrady Sejmu ustawa prasowa ..." - z tez V Zjazdu PZPR, „Trybuna Ludu” 18 października 1968 r., nr 313.

52 Por. § 2 zarządzenia nr 52 Prezesa RM z 20 lutego 1957 r. w sprawie udzielania zezwoleń na wydawanie periodyków (niepublikowane).

${ }^{53}$ Rozporządzenie Prezesa RM w sprawie zakresu i trybu sprawowania nadzoru i kontroli przez organy kontroli prasy, publikacji i widowisk, Dz. U. z 1970 r. nr 6, poz. 50.

${ }^{54}$ Ustawa o zakresie działania Komitetu do Spraw Radia i Telewizji, Dz. U. z 1960 r. nr 54, poz. 307; por. ustawę o łączności, Dz. U. z 1961 r. nr 8, poz. 48.

${ }^{55}$ Rozporządzenie RM w sprawie zmian organizacji wydawniczej i kolportażu prasy, Dz. U. z 1972 r. nr 55, poz. 367. 
zany jest z demokratyzacją życia politycznego, umożliwiającą realizację zasady jawności działalności państwowej. Praktyka w udostępnianiu informacji przejawiała się w powoływaniu w jednostkach państwowych rzeczników prasowych, wydawaniu, wbrew przepisom z 1950 r., biuletynów informacyjnych, organizowaniu konferencji prasowych itp., jednym słowem - pełniejszym charakterze udzielanych prasie informacji. Zasadniczym unormowaniem $\mathrm{w}$ tej mierze było zarządzenie Prezesa RM z 10 listopada 1956 r. w sprawie udostępniania danych liczbowych, informacji statystycznych i innych materiałów służbowych. ${ }^{56} \mathrm{Akt}$ ten uprawniał kierowników instytucji państwowych do udzielania informacji. Ze względu na pozostawienie decyzji o udostępnieniu danych do swobodnego uznania wskazanych podmiotów zarządzenie to stanowiło wątłą podstawę prawa do informacji, szczególnie w sytuacji gdy przepisy o ograniczeniu przepływu informacji, pochodzące z 1950 r., nie zostały uchylone. W wytworzonej w ten sposób dwuznacznej sytuacji prawnej należy szukać przyczyn dowolności w powoływaniu np. w centralnych organach administracji rzeczników prasowych i określaniu ich kompetencji oraz zakresu danych przekazywanych prasie.

Badania przeprowadzone przez Ośrodek Badań Prasoznawczych ${ }^{57}$ w 31 ministerstwach i centralnych urzędach dają obraz faktycznego dostępu prasy do źródeł informacji za pośrednictwem czy przy pomocy rzeczników prasowych. Tylko w 8 spośród 31 instytucji stwierdzono korzystne dla prasy unormowanie tej kwestii. W dwóch organach, w których nie powołano rzeczników prasowych, ich kierownicy oświadczyli, że „nie widzą potrzeby kontaktów z prasą” (Komisja Planowania przy RM i Komitet Pracy i Płac). W pozostałych ministerstwach i urzędach unormowanie dostępu dziennikarzy do informacji faktycznie służyło zamknięciu resortu przed prasą i przed opinią publiczną. ${ }^{58}$

Skoro tak, to wyniki działalności państwowej jawią się przed dziennikarzami, szczególnie prasy lokalnej, której kontakty z centralnymi instytucjami są minimalne, jako fakty, o których wiedzą oni tyle co przeciętny obywatel. W takiej sytuacji nie ma mowy o całościowym komentowaniu, krytykowaniu działań aparatu państwowego w czasie podejmowanych decyzji. ${ }^{59}$

Przyczyn tego stanu rzeczy prowadzący badania upatrywali zarówno w obowiązywaniu przestarzałych przepisów z 1950 r., jak i wewnętrznym normowaniu przez resorty pozycji rzeczników prasowych. Słusznie więc postulowano uchylenie przepisów z 1950 r., uregulowanie statusu rzecznika prasowego przepisa-

${ }^{56} \mathrm{MP}$ nr 102, poz. 1182.

${ }^{57}$ I. Tetelowska, Ze studiów nad źródłami informacji, OSBP, Kraków 1974.

${ }^{58}$ Przykładowo okólnik nr 11 z 1971 r. Ministra Żeglugi uzależniał udzielenie informacji dziennikarzowi od skierowania uzyskanego od rzecznika prasowego resortu; zarządzenie Ministra Sprawiedliwości z dnia 1 stycznia 1972 r. w sprawie obsługi prasowej resortu i współpracy ze środkami rozpowszechniania informacji uzależniało udzielenie informacji od zgody ministra.

${ }^{59}$ I. Tetelowska, op. cit., s. 8. 
mi niepochodzącymi od organów, w których są zatrudnieni, a w konsekwencji zagwarantowanie rzecznikowi pozycji niezależnej od kierownictwa resortu, by mógł stać się reprezentantem interesów nie ministra, ale kontroli społecznej. ${ }^{60}$

W trzecim okresie dostęp do informacji normowało: zarządzenie nr 12 Prezesa RM z 23 stycznia 1963 r., w sprawie udostępniania danych liczbowych, informacji statystycznych i innych materiałów służbowych ${ }^{61}$, zarządzenie nr 54 Prezesa RM z 4 marca 1963 r. normujące udostępnienie tych samych danych prasie ${ }^{62}$, pismo okólne 59 Prezesa RM z 28 października 1965 r. w sprawie publikowania wiadomości o wykonaniu lub przekroczeniu zadań planowych, pismo premiera z 22 kwietnia 1971 r. w sprawie informowania środków przekazu przez administrację państwową i gospodarczą. Wymienione zarządzenie $\mathrm{nr} 12$ było pierwszym aktem normującym kompleksowe zasady udostępniania informacji. Nie jest to jednak niestety równoznaczne z zadowalającym uregulowaniem. Zarządzenie to normowało jedynie uprawnienie, a nie obowiązek udzielania informacji. Dotyczyło ono jedynie organów państwowych podporządkowanych rządowi, a uprawnieni do informowania zostali wyłącznie kierownicy tych organów. Udostępnienie danych uzależnione zostało od wielu warunków, takich jak pisemny wniosek odpowiednich jednostek czy określenie zakresu ich wykorzystania. Ponadto zasadą było udostępnienie tylko materiałów jawnych. $\mathrm{O}$ tym, jak dalece zarządzenie to było nieużyteczne jako podstawa ubiegania się prasy o dostęp do źródeł informacji, niech świadczy fakt, iż już półtora miesiąca później premier wydał zarządzenie uchylające wcześniejsze postanowienia $\mathrm{w}$ odniesieniu do przedstawicieli prasy - zarządzenie nr 54 zobowiązywało do udzielania informacji. Obowiązek ten spoczywał nie tylko na kierownikach jednostek wymienionych w zarządzeniu nr 12, ale również na kierownikach poszczególnych komórek organizacyjnych danej jednostki, nie zawierało wymogu pisemnego wniosku o udostępnienie danych ani niektórych ograniczeń dotyczących wykorzystania uzyskanych informacji. ${ }^{63}$

Dwa następne akty premiera normowały jedynie wąski wycinek prawa do informacji. Pismo okólne z 1965 r. ograniczało obowiązek udzielania informacji w sprawach gospodarczych, uzależniając podanie informacji od decyzji organów nadrzędnych, zaś pismo z 1971 r. zawierało ogólne zalecenia pełniejszego informowania środków masowego przekazu. Formalne obowiązywanie do $1978 \mathrm{r}$. przepisów z $1950 \mathrm{r}$. utrudniających dopływ informacji, niska ranga aktów premiera regulujących prawo do informacji, brak w nich gwarancji chroniących przed naruszeniem ich postanowień spowodowały, że w omawianym okresie nie na-

\footnotetext{
${ }^{60}$ Ibidem, s. 54.

${ }^{61} \mathrm{MP}$ nr 9, poz. 427.

${ }^{62} \mathrm{MP}$ nr 20, poz. 108.

${ }^{63}$ Bliżej na ten temat B. Michalski, Prawo dziennikarza do informacji, Kraków 1974, s. 17-44.
} 
stąpiły istotne zmiany w organizacji służby informacyjno-prawnej w resortach ${ }^{64}$, a stan praktyki pozostawiał wiele do życzenia. Ocena taka legła u podstaw uchwały Biura Politycznego KC PZPR z 22 lutego 1977 r. „O dalsze doskonalenie działalności informacyjno-publicystycznej oraz umocnienie ideowo-wychowawczej roli krytyki w prasie, radio i telewizji”. Kierując się tą uchwałą, Rada Ministrów podjęła uchwałę nr 19 z 17 stycznia 1978 r. w sprawie dalszego usprawnienia informacji dla środków masowego przekazu. ${ }^{65}$ Stanowi ona niewątpliwy postęp w unormowaniu podstawowego elementu wolności słowa, jednocześnie jednak mając na uwadze normowaną materię i fakt, że akt ten ukazał się dopiero w 26 lat od uchwalenia Konstytucji PRL, zastrzeżenia budzi zarówno forma regulacji uchwała rządu, jak i treści niektórych postanowień. Do pozytywnych cech normowania omawianej uchwały należy zaliczyć m.in. wprowadzenie zasady udostępniania prawie wszelkich materiałów $\mathrm{z}$ wyjątkiem stanowiących tajemnicę państwową i służbową, uregulowanie podstawowych praw i obowiązków prasy, zadań rzeczników prasowych, zakazu tłumienia krytyki prasowej. Uchwała uzupełniła obowiązujące przepisy kodeksu postępowania administracyjnego w zakresie reagowania na krytykę prasową. Nadesłane do organu lub jednostki materiały krytyczne powinny być rozpatrywane przez kierownictwo z udziałem przedstawicieli organizacji politycznych i społecznych działających na terenie organu lub jednostki. W odpowiedzi na te materiały podmioty te nie tylko mają obowiązek zawiadomić redakcję o sposobie załatwienia sprawy (art. 177 § 2 k. p. a.), ale również o sposobie wykorzystania przekazanych uwag ( $\$ 6$ ust. 8 uchwały). Redakcja ma z kolei obowiązek publikacji merytorycznych odpowiedzi na inicjatywy redakcyjne i publikacje krytyczne (§ 7 ust. 1 uchwały).

Z kolei wśród licznych zastrzeżeń należy wymienić: niczym nieumotywowane ograniczenie, w porównaniu z postanowieniami zarządzenia Prezesa RM z 1963 r., kręgu osób zobowiązanych do udzielenia informacji, ogólnikowe unormowanie prawa redakcji do odwołania się w razie odmowy udzielenia informacji, uzależnienie pozycji rzeczników od resortu w związku z zakazem łączenia tych stanowisk z etatową pracą dziennikarską. Przepisy dotyczące ochrony osób udzielających informacji ${ }^{66}$ i sprostowań prasowych ${ }^{67}$ są sformułowane w sposób powodujący różne wątpliwości interpretacyjne, a tym samym trudności w ich stosowaniu.

Aktem uzupełniającym omawiane przepisy jest nowa regulacja statusu Rzecznika Prasowego Rządu. Realizując społeczny postulat zwiększenia jawno-

${ }^{64}$ Ibidem, s. 108.

${ }^{65}$ MP nr 5, poz. 21. Uzupełnienie stanowi uchwała RM z dnia 17 lutego 1978 r. w sprawie zakresu i trybu działania Rzecznika Prasowego Rządu (niepublikowane).

${ }^{66}$ Ze sformułowania $\S 6$ pkt 6 wynika bowiem, iż przepisy uchwały chronią informatora w mniejszym zakresie niż kodeks karny.

${ }^{67}$ Por. fragmentaryczne unormowanie tej kwestii w $§ 7$ cyt. uchwały. 


\section{8}

ści poczynań aparatu państwowego i dostępu do informacji, rząd podjął w grudniu 1980 r. uchwałę w sprawie zakresu i trybu działania Rzecznika Prasowego Rządu. ${ }^{68}$ Organ ten jest powołany do informowania o pracach rządu, sytuacji społeczno-gospodarczej kraju, przedstawiania stanowiska rządu w sprawach polityki wewnętrznej i zagranicznej, jak również zapewnienia dziennikom dostępu do informacji (§ 1). W wykonaniu tych zadań Rzecznik Prasowy Rządu zobowiązany jest m.in. do organizowania konferencji prasowych, przekazywania redakcjom w formie biuletynów materiałów na temat sytuacji społeczno-gospodarczej, pomocy w uzyskaniu informacji prasowych, kontrolowania realizacji zadań określonych w cytowanej wyżej uchwale nr 13 RM z 1978 r., w szczególności w zakresie reagowania jednostek państwowych na krytykę prasową. O wynikach swej działalności rzecznik informuje zarówno rząd, jak i premiera. Uchwała generalnie zobowiązuje organy $i$ instytucje państwowe do udzielania rzecznikowi niezbędnych wyjaśnień oraz udostępnienia materiałów. Rzecznik Prasowy Rządu ma również istotny wpływ na określenie zakresu udostępnianych przez administrację danych i informacji - jest on upoważniony do ustalania z ministrami i kierownikami urzędów i instytucji centralnych kierunków działalności informacyjnej rzeczników prasowych lub innych osób odpowiedzialnych za współpracę ze środkami masowego przekazu (§ 3 ust. 4).

Omawiana regulacja, pomijając jej braki, stanowi jedynie środek doraźny, wypełniając swymi fragmentarycznymi przepisami niewielką część luki w całościowym normowaniu dostępu do informacji przez prasę i zasad jej funkcjonowania. Potrzebą palącą jest w tej mierze unormowanie ustawowe prawa prasowego nad projektem, wokół którego trwają już prace przygotowawcze.

W okresie obowiązywania konstytucji brak jest najczęściej kompleksowych rozwiązań prawnych także w odniesieniu do innych niż środki masowego przekazu form korzystania z wolności słowa.

Bardzo ogólne postanowienia w tej mierze znalazły się początkowo w ustawie z 1961 r. o zakresie działania Ministra Kultury i Sztuki, a obecnie w ustawie o urzędzie Ministra Kultury i Sztuki z 4 maja 1982 r. ${ }^{69}$ Zgodnie z jej postanowieniami zakres działania Ministra Kultury i Sztuki obejmuje m.in. sprawy: działalności artystycznej, widowiskowej i rozrywkowej, kinematografii, wydawnictw, przemysłu poligraficznego, muzycznego i fonograficznego. Szczegółowe przepisy zawarte zostały w rozporządzeniu $\mathrm{RM}^{70}$, które określiło, że do właściwości Ministra Kultury i Sztuki należy nadzór nad organizacją i działalnością wydawnictw, koordynacja działalności jednostek wydawniczych, księgarskich, podległych jednostkom państwowym, spółdzielczym i organizacjom społecznym, jak również

\footnotetext{
${ }^{68} \mathrm{MP}$ nr 31, poz. 172.

${ }^{69}$ Dz. U. nr 14, poz. 112.

${ }^{70}$ Dz. U. z 1961 r. nr 10, poz. 56.
} 
udzielanie na podstawie obowiązujących przepisów zezwoleń na prowadzenie działalności wydawniczej, księgarskiej, na publiczną działalność rozrywkową oraz produkcję, rozpowszechnianie i wyświetlanie filmów. Klauzula o działalności na podstawie dotychczasowych przepisów oznaczała stosowanie unormowań, co do których były już podnoszone zarzuty dotyczące zarówno ich formy, jak i merytorycznych rozwiązań.

Dostosowanie przepisów do zmieniających się warunków następowało często za pomocą aktów wewnętrznych. W odniesieniu np. do działalności wydawniczej jednostek gospodarki nieuspołecznionej dotyczącej książek i druków nieperiodycznych dokonało się to przez zarządzenia z 1959 r. zmienione w latach $70 .{ }^{71}$ W dziedzinie kinematografii ramowa ustawa z $1951 \mathrm{r}$. obowiązuje ze zmianami do dziś, a akty ją wykonujące, mimo zmian, nie zrewidowały ustalonych w początkach lat 50. zasad dyskrecjonalnej władzy administracji w dziedzinie produkcji i rozpowszechniania filmów. ${ }^{72}$

Unormowanie publicznej działalności artystycznej, rozrywkowej i sportowej obrazuje skutki obowiązywania przestarzałych przepisów i aktualizacji ich aktami instrukcyjnymi. Tą sferę korzystania ze swobody wypowiedzi normowała do 1968 r. ustawa z 1933 r. wraz z aktami wykonawczymi pochodzącymi z tego samego okresu. W latach 1957-1961 wydanych zostało również wiele aktów instrukcyjnych. ${ }^{73}$ Wyniki kontroli NIK przeprowadzonych na wniosek Sejmowej Komisji Kultury i Sztuki wykazały przestarzałość przepisów i nierespektowanie wydanych aktów instrukcyjnych. Do przyczyn takiego stanu rzeczy należało zaliczyć przede wszystkim ,wielość różnego rodzaju przepisów obowiązujących $\mathrm{w}$ tej dziedzinie, $\mathrm{z}$ których podstawowe pochodziły jeszcze $\mathrm{z}$ okresu przedwojennego i brak aktualnego jednolitego aktu prawnego wysokiej rangi w postaci ustawy ${ }^{74}$ Mimo jednak wniosku Komisji Sejmowej, która domagała się jak najszybszego przygotowania projektu ustawy, rząd zwlekał z tym 8 lat.

W ciągu blisko 30 lat obowiązywania Konstytucji PRL, a więc do chwili uchwalenia nowej ustawy o cenzurze, nie zostały bliżej sprecyzowane (nie licząc postanowień kodeksu karnego) granice wolności słowa i druku. W porównaniu z ogólnymi granicami wskazanymi w dekrecie o utworzeniu GU KPPiW były one formułowane nawet szerzej. Ustawa o prawie autorskim z $1952 \mathrm{r}$. w art. 38 $\S 2$ uprawniła wydawcę do odstąpienia od wydania utworu, jeżeli jego wydanie byłoby „sprzeczne z interesem Państwa Ludowego”. Ustawa z 1968 r. o publicznej działalności artystycznej i rozrywkowej zakazywała m.in. działalności ,,szko-

\footnotetext{
${ }^{71}$ Por. Dz. Urz. MKiSz z 1971 r. nr 2, poz. 6 i 7.

${ }^{72}$ Por. zarządzenie Ministra Kultury i Sztuki w sprawie produkcji filmów przeznaczonych do publicznego wyświetlania, MP z 1965 r. nr 10, poz. 36,

${ }^{73} \mathrm{Na}$ temat ich roli - por. Sprawozdanie stenograficzne z 19 posiedzenia Sejmu w dniach 9-11 kwietnia $1968 \mathrm{r}$., tam 53/54.

${ }^{74}$ Ibidem, łam 54.
} 
dliwej dla interesu państwowego i społecznego". Podobnie klauzule generalne napotkać można zarówno w innych aktach o randze ustawy ${ }^{75}$, rozporządzeniach $^{76}$, jak i w aktach wewnętrznych. ${ }^{77}$

Istotne zmiany przyniosło uchwalenie w $1981 \mathrm{r}$. ustawy o kontroli publikacji i widowisk. ${ }^{78}$ Jej celem jest niewątpliwie ograniczenie dyskrecjonalności, a czasami wręcz arbitralności organów podstawowych, ingerujących w konstytucyjną wolność obywateli. Na newralgiczność społeczną problemu cenzury wskazało porozumienie podpisane w sierpniu 1980 r. między strajkującymi załogami robotniczymi a rządem. Warto więc poświęcić nieco miejsca nowej ustawie o cenzurze.

Ustawa ta, uchwalona przez Sejm 31 lipca 1981 r., oceniona została jako akt „rozsądnego kompromisu” między zachowawczymi tendencjami reprezentowanymi przez rząd we wstępnym projekcie a radykalizmem wyrażonym w projekcie społecznym. Utrzymano wprawdzie system cenzury prewencyjnej, ale ustawa dała jednocześnie wyraz temu, że zasadą jest wolność słowa, swobodne jego tworzenie i rozpowszechnianie, zaś ograniczenia są wyjątkiem, powinny więc być taksatywnie i w miarę precyzyjnie określone. Wprowadzono również zobiektywizowaną sądową kontrolą decyzji cenzorskich. Omawiana ustawa w sposób jakościowy odbiega od sposobu unormowania analogicznych zagadnień w dekrecie z $1946 \mathrm{r}$. Różnicę tę wyraża przede wszystkim przepis art. 1. Ustawa zapewnia w nim wolność słowa i druku i gwarantuje realizację tego przez nałożenie obowiązku jej ochrony przez organy i instytucje państwowe oraz organizacje polityczne i społeczne. Oznacza to, że wskazane podmioty powinny w swej działalności zwracać szczególną uwagę na prawidłowe rozumienie wolności słowa i podejmować odpowiednie działania z własnej inicjatywy lub na wniosek zainteresowanych w przypadku naruszenia swobody wypowiedzi. Granice wolności słowa i ingerencji cenzorskich wyznaczono $\mathrm{w}$ dwojaki sposób. Po pierwsze ustawa określa $\mathrm{w}$ art. 2, co stanowi nadużycie wolności słowa. W artykule tym precyzyjniej niż w dekrecie z 1946 r. i wstępnym projekcie ustawy wymieniono działania zakazane. Ich sformułowanie słusznie nawiązuje do przepisów kodeksu karnego. ${ }^{79}$ Po drugie taksatywnemu wyliczeniu poddane są przypadki wyłączenia spod kontroli (art. 4). Analiza tych wyłączeń przekonuje o znacznej liberalizacji dotychczaso-

${ }^{75}$ Por. art. 13 prawa celnego, Dz. U. z 1975 r. nr 10, poz. 56.

${ }^{76}$ Por. $\S 5$ rozporządzenia Prezesa RM w sprawie zakresu i trybu sprawowania nadzoru i kontroli przez Główny Urząd Kontroli Prasy, Publikacji i Widowisk, Dz. U. z 1975 r. nr 13, poz. 75.

${ }_{77}$ Por. $§ 2$ zarządzenia nr 65 Ministra Nauki, Szkolnictwa Wyższego i Techniki z dnia 4 listopada 1976 r. w sprawie trybu sprawowania nadzoru nad pomocami dydaktycznymi..., Dz. Urz. MNSzWiT nr 13, poz. 48.

${ }^{78}$ Dz. U. nr 20, poz. 99.

${ }^{79}$ Konkretyzacją postanowień dekretu w odniesieniu do tajemnicy państwowej i służbowej jest ustawa o ochronie tajemnicy państwowej i służbowej z 1982 r., Dz. U. nr 40, poz. 271. 
wych zasad. Rozszerzenie ustawowych wyłączeń możliwe jest ponadto na mocy decyzji Głównego Urzędu Kontroli Publikacji i Widowisk, wydanej na wniosek zainteresowanego redaktora, wydawcy lub wystawcy (art. 4 ust. 2).

Do odchodzenia od ścisłej reglamentacji istotne znaczenie ma również przepis art. 5, który stanowi, że organy cenzury nie mogą ustanawiać zakazów publikacji i widowisk określonych autorów oraz wydawać wytycznych interpretacyjnych w sprawie sposobu przedstawiania wydarzeń, działalności instytucji i poszczególnych osób. ${ }^{80}$

Ustawa wprowadziła nowy model cenzury. Organem uprawnionym do prowadzenia kontroli wstępnej pozostał Urząd Kontroli Publikacji i Widowisk, zbudowany aktualnie na podstawie zasady dwuinstancyjności. Organem centralnym jest Główny Urząd KPiW, który posiada podległe organy - okręgowe urzędy. Urząd ten przestał być organem rządowym, został bowiem podporządkowany Radzie Państwa ${ }^{81}$, która powołuje i odwołuje Prezesa i wiceprezesów Głównego Urzędu, członków jej kolegium, nadaje statut, określa regulamin funkcjonowania Urzędu, rozpatruje okresowe sprawozdania. Rozpatrując te sprawozdania, Rada Państwa korzysta z opinii I Prezesa Sądu Najwyższego i Prokuratora Generalnego i Prezesa Naczelnego Sądu Administracyjnego. Rada Państwa została ponadto zobowiązana do składania Sejmowi corocznych sprawozdań ze swej działalności podejmowanej w stosunku do cenzury. Powinno to umożliwić lepszą kontrolę organów cenzury przez publiczną debatę w Sejmie.

Zmianie uległ system środków odwoławczych. Decyzje okręgowych urzędów, jako organów I instancji, o zakazie rozpowszechniania publikacji mogą być zaskarżone w trybie administracyjnym do Głównego Urzędu. Na decyzję Głównego Urzędu przysługuje zaś skarga do Naczelnego Sądu Administracyjnego. Do całego postępowania odwoławczego i skargowego mają zastosowanie przepisy k.p.c., chyba że ustawa stanowi inaczej. Dotyczy to głównie określenia terminów decyzji i rozpatrywania odwołań. Są one ze zrozumiałych względów skrócone, co ma szczególne znaczenie w odniesieniu do publikacji, które mogą utracić swój walor z upływem krótkiego czasu, np. informacje prasowe. Poddanie zasad postępowania w sprawach należących do organów kontroli publikacji i widowisk przepisom k.p.a. ma na celu zapewnienie legalizmu w działalności tych organów. Każda negatywna decyzja musi wskazywać podstawę prawną oraz uzasadnienie. Każda z nich może ostatecznie stać się przedmiotem kontroli sądowej sprawowanej przez NSA. ${ }^{82}$

\footnotetext{
${ }^{80}$ Unormowanie to jest korzystne także dla cenzorów. Nie muszą już zasiadać do pracy zaopatrzeni w liczne i bardzo często zmieniające się „zapisy”.

${ }^{81}$ Nie jest to rozwiązanie istotnie różniące się od podporządkowania rządowi, jeżeli zważyć faktyczny zakres zależności Rady Państwa od Sejmu.

${ }^{82}$ Pierwszą skargę na decyzję GU KPiW NSA rozpatrzył 3 listopada 1981 r. a więc już w miesiąc po wejściu w życie ustawy. NSA uchylił zaskarżoną decyzję Głównego Urzędu.
} 
Ustawa o kontroli publikacji i widowisk stanowi znaczny postęp ${ }^{83} \mathrm{~W}$ procesie demokratyzacji regulacji prawnych dotyczących wolności słowa i druku. O trwałości tych przemian świadczy pośrednio fakt, iż ustawa z 25 stycznia $1982 \mathrm{r}$. o szczególnej regulacji prawnej w okresie stanu wojennego ${ }^{84}$ przywróciła uchylone dekretem o stanie wojennym prawo do zaskarżania decyzji administracyjnych, w tym cenzorskich, do sądu administracyjnego.$^{85}$

\section{Próba oceny stanu prawnego}

Rozwój regulacji prawnych wolności słowa i druku na gruncie Konstytucji PRL daje podstawę do sformułowania ogólniejszych uwag dotyczących zarówno ich formy, jak i treści. Ustawowe normowanie stanowi niewielką część regulacji wolności słowa. Akty te są bardzo często ramowe, ich postanowienia ogólnikowe, zaś upoważnienia do wydania aktów wykonawczych mają w wielu wypadkach charakter blankietowy. Szereg aktów ustawowych pochodzących z okresu 19441952, jak i wcześniejszego obowiązywało wiele lat po uchwaleniu konstytucji, mimo ich dezaktualizacji. Rozwój ustawodawstwa w 30-leciu PRL nie wypełnił $\mathrm{w}$ zadowalającym stopniu istniejących luk. Konstatowano wprawdzie potrzebę uchwalenia nowych przepisów, częstokroć zapowiadano ich zainicjowanie, lecz prace przygotowawcze nad projektami ciągnęły się latami i nie zawsze kończyły się wniesieniem projektu do Sejmu. Tylko część winy ponosi za to działalność Sejmu, w szczególności komisji, które zaniedbywały obowiązek kontroli wykonania ustaw, nie wykorzystywały wszystkich przysługujących im środków wpływania na działalność legislacyjną rządu. W dużej mierze na istniejącym stanie zaważyły znane powszechnie słabości prawotwórstwa organów administracji państwowej, a przede wszystkim praktyka życia politycznego, ogniskująca się w charakterze relacji partia-rząd-Sejm.

${ }^{83}$ Nie znaczy to, by ustawa była bez wad. Wątpliwości budzi np. wyłączenie spod obowiązku kontroli nie wszystkich aktów prawnych, lecz jedynie aktów normatywnych i innych aktów o charakterze ogólnym, chybione wydaje się przekazanie możliwości pozbawienia debitu zagranicznych druków okręgowym urzędom kontroli publikacji i widowisk, nie jest jasne, wobec braku wyraźnej derogacji dotychczasowych przepisów określających szeroko możliwość ograniczeń wolności słowa, w jakim zakresie przepisy te nadal obowiązują.

${ }^{84}$ Dz. U. nr 3, poz. 18.

${ }^{85}$ Wśród ograniczeń wolności słowa wprowadzonych na okres stanu wojennego i jego zawieszenia należy przede wszystkim wymienić ograniczenie zakresu wyłączeń spod kontroli wstępnej, ograniczenie użytkowania zakładów poligraficznych, urządzeń do wykonywania druków, ilustracji, pieczątek i stempli, upoważnienie Prezesa GU KPiW do ustalenia zasad i trybu udzielania zezwoleń na rozpowszechnianie publikacji i widowisk, użytkowanie zakładów poligraficznych i wskazanych wyżej urządzeń oraz wprowadzenie dodatkowej klauzuli, uzasadniającej zakaz publikacji w postaci „Zagrożenia dla interesów bezpieczeństwa i obronności państw” (art. 17 dekretu o stanie wojennym). 
Braki aktów ustawowych bądź ich nieobecność w porządku prawnym skutkowały wydawaniem aktów rządowych formalnie wykonawczych, a faktycznie zastępujących ustawy. Zjawisko takie, niekorzystne rzecz jasna, z punktu widzenia zasady supremacji ustawy ułatwiał sposób normowania niektórych ustaw, który nie mógłby determinować treści aktów wykonawczych nie tylko z powodu np. przestarzałości przepisów, ale i dlatego, że nie pretendowały do tego. Wielokrotnie ustawy odsyłały do przepisów aktów wykonawczych, powierzając im określenie zasad korzystania i ograniczenia wolności słowa bądź po prostu zagadnienia te pomijały milczeniem. Jedynie formalnie wykonawczy charakter aktów rządowych spowodował w dłuższym czasie, przy nasileniu się tego zjawiska, autonomizację porządku podustawowego. Znane są przypadki niewydawania aktów wykonujących ustawy trwające kilka czy kilkanaście lat, uchwalanie ich kilkakrotnie na tej samej podstawie prawnej i regulujących określone materie na różnych zasadach. W sytuacji, w której rozporządzenie czy uchwała zastępuje ustawowe normowanie, powszechną praktyką jest korzystanie z instytucji pododesłań do aktów niższego rzędu. Wydłuża to znacznie drogę do zastosowania postanowień aktu nadrzędnego. Zdarza się również, że rządowe akty prawne przekazują regulację zagadnień wiążących się z korzystaniem z wolności słowa jedynie do kompetencji właściwych organów bez wskazania, na jakich zasadach ma się to odbywać. Siłą rzeczy regulacja prawna oparta jest wówczas na samoistnych aktach wewnętrznych, z reguły niepublikowanych.

Grupa tych aktów w dziedzinie normowania wolności słowa jest stosunkowo liczna i charakteryzuje się tymi samymi słabościami co cały system prawa powielaczowego, a więc brakiem spójności regulacji, nierespektowaniem zasad techniki prawodawczej, w szczególności poprawności terminologicznej, doraźnością rozwiązań, a w konsekwencji powoduje to obowiązywanie albo aktów zdezaktualizowanych albo z kolei ich ciągłe zmiany. Analizując treść tych aktów, trudno się często dopatrzeć jakichś stałych zasad.

Akty instrukcyjne cechuje ponadto w znacznie większych rozmiarach niż inne regulacje brak zgodności z przepisami o charakterze nadrzędnym ${ }^{86}$ oraz niski stopień skuteczności. Taki stan prawny spowodował, że ustalanie warunków i zasad korzystania ze swobody wypowiedzi, stawianie barier ograniczających konstytucyjną zasadę przez długi okres obowiązywania konstytucji należało często do uznania organów administracji. Prowadziło to do poważnego ograniczenia wolności słowa m.in. z zakresu informacji i publicystyki. ${ }^{87}$ Powolne wychodzenie $\mathrm{z}$ tego stanu, na co wskazuje uchwalenie nowej ustawy o cenzurze, ochronie

${ }^{86}$ Por. B. Michalski, Podstawowe metodologiczne problemy badań prawnych zwiazanych z działalnościa środków przekazu informacji, [w:] Metody i techniki badań w prasoznawstwie, t. II, 1970, s. 195 i n.

${ }^{87}$ B. Michalski, Granice prawne swobody wypowiedzi prasowej w PRL, ,Biuletyn ZG RSW „Prasa” 1970, nr 12, s. 54. 
tajemnicy państwowej i służbowej, przygotowywanie prawa prasowego, powinno się odbywać drogą kompleksowych unormowań ustawowych, realizujących postanowienia ustawy zasadniczej. Na gruncie bowiem jej obowiązywania dał się wprawdzie zauważyć proces demokratyzacji przepisów dotyczących wolności słowa zawartych w aktach niższego rzędu; był on jednak zbyt mało radykalny, a okresami wręcz zamierał.

Analiza unormowań wolności słowa i druku z okresu obowiązywania konstytucji (1952-1968) uzasadniła ocenę stanu prawnego jako „niezadowalającego, charakteryzującego się rozproszeniem norm, ich przestarzałością i licznymi lukami" ${ }^{88}$ Ocena ta jest w pewnym stopniu aktualna i dziś.

Można zasadnie stwierdzić, że normy konstytucji w założeniu determinujące istotne elementy treści i formy wolności słowa nie wywarły w rzeczywistości wpływu na rozwój prawnej jej regulacji. W świetle praktyki prawotwórczej konstytucyjną wolność słowa można zdefiniować jako prawo wypowiadania i wymiany poglądów, ze szczególnym uwzględnieniem poglądów politycznych, w warunkach częściowej monopolizacji środków masowego przekazu, przewagi administracyjnych metod wpływu na korzystanie przez obywateli z wolności słowa, przyznaniu szerokiej dyskrecjonalnej władzy administracji państwowej w tej mierze. Powstaje pytanie, w jakim stopniu wpływ na tak ukształtowaną praktykę miało ogólnikowe normowanie konstytucji. Jest to ważki problem, gdyż od jego rozwiązania będzie zależeć m.in. stwierdzenie skali koniecznych zmian w ustawie zasadniczej. Wydaje się, że brakom regulacji konstytucyjnej nie można przypisywać zbyt wiele $\mathrm{w}$ zakresie odpowiedzialności za istniejący stan. Niedostatki normowania Konstytucji PRL są jedynie jedną z kilku przyczyn. W równej mierze na istniejącej praktyce zaciążyło przypisywanie przez jej twórców głównie roli politycznej temu aktowi prawnemu, co rzutowało na nieuczestniczenie konstytucji w przemianach ustrojowych. Poważny wpływ miały również nieprawidłowości w działalności legislacyjnej, szczególnie dotkliwe wobec braku w systemie organów państwowych skutecznego mechanizmu służącego kontroli konstytucyjności prawa.

Zmiany w regulacji prawnej wolności słowa i druku powinny więc być oparte zarówno na pełniejszym i precyzyjniejszym sformułowaniu postanowień konstytucji, zreformowaniu zasad działalności prawotwórczej, uporządkowaniu systemu źródeł prawa - czemu powinno służyć uchwalenie ustaw o tworzeniu prawa i Trybunale Konstytucyjnym. Dopiero łączne spełnienie tych warunków pozwoli ustawie zasadniczej wypełniać rolę czynnego źródła prawa i gwaranta praw obywateli.

${ }^{88}$ B. Michalski, Prawo do informacji, „Prasa Polska” 1968, nr 9, s. 3. 


\section{SUMMARY}

A brainchild of this study has been rooted in works of G. H. Carr and B. Croce. They wrote: All history is "contemporary history", meaning that history consists essentially in seeing the past through the eyes of the present and in view of its problems, and that the main work of the historian is not to record but to evaluate; for, if he does not evaluate, how can he know what is worth recording? Therefore, the author decided to show, by presenting his unpublished paper (banned by censorship in 1984), how the State curbed, especially through legislation, a freedom of expression during a communist rule. The text remains untouched in a substance and form to see the past through the eyes of... the past.

The paper consists of three parts. The first is devoted to an idea of regulation of freedom of expression in view of the Polish People's Republic Constitution (1952). The author discusses the influence of a communist ideology upon a shape and contents of constitutional statements. In the second part, a substance of legislation on freedom of expression is examined. The study concerns the State legislative activity during almost forty years, and it shows a slight, gradual improvement but - at the same time - some permanent defects. The third section is devoted to the conclusions on necessary changes in constitutional and statutes regulations concerning the freedom that is under discussion. 